member of the pueblo. The woodland is, at least in theory, communal property. The gradations from indigenous to more or less European tradition give pages of special interest to this book.

\section{High-Vacuum Equipment}

Particulars have recently been received from Messrs. W. Edwards and Co. (London), Ltd., Kangley Bridge Road, London, S.E.26, of several new devices which they manufacture for use with pumps and vacuum equipment. These include controllable leaks for the continuous admission of small quantities of gas to a vacuum system. A dial allows any particular setting of the valve to be noted and repeated. The other equipment consists of various combinations of bellows and micro-switches to form pressurecontrolled relays capable of operating a half-horsepower A.c. motor. One version can be used to switch off power supplies, or start a motor, when the pressure in a vacuum system reaches any predetermined value between 15 and $500 \mathrm{~mm}$. of mercury. Another application is as a safety device which comes into play when the rate of flow of liquid in a tube falls outside chosen limits. This instrument is also supplied in a form which indicates the rate of flow on a dial. No doubt many applications of these units will be found in apparatus which has to run for long periods without attention.

\section{Colonial Services: Recent Appointments}

THE following appointments in the Colonial Services have been announced: J. S. Campbell, agricultural officer, Nigeria; H. D. Matheson, agricultural officer, Federation of Malaya; D. J. Parsons, agricultural officer, Uganda; J. B. D. Robinson, chemist, Department of Science and Agriculture, Barbados ; J. W. F. Chapman, assistant conservator of forests, Nigeria; D. A. Francis, assistant conservator of forests, Gold Coast ; F. W. Binge, geologist, Kenya; T. C. James, geologist, Tanganyika; D. L. Searle, geologist, Kenya; R. B. Smith, agricultural officer, Trinidad; M. E. R. Taylor, assistant conservator of forests, British Guiana; J. H. Wheelan, assistant conservator of forests, Gold Coast ; H. Gillman (agricultural officer, Tanganyika), senior agricultural officer, Tanganyika; R. Johns (agricultural adviser to the comptroller of development and welfare, West Indies), deputy director of agriculture (regional), Nigeria; R. W. R. Miller (agricultural officer, Federation of Malaya), director of agriculture, Sarawak; A. Smith (rural education officer, Gold Coast), principal agricultural education officer, Gold Coast; F. E. Hughes (senior assistant conservator of forests, Gold Coast), conservator of forests, Gold Coast.

\section{University of London}

THe title of professor emeritus in the University of London has been conferred on the following : Sir Alexander Fleming, professor of bacteriology in St. Mary's Hospital Medical School since 1928; Sir Francis Fraser, professor of medicine and physician in St. Bartholomew's Hospital Medical College during 1920-34 and professor of medicine in the British Postgraduate Medical School during 1934-46 ; Prof. H. Gordon Jackson, professor of zoology in Birkbeck College since 1928, and master of the College; and Prof. C. H. Lobban, formerly head of the Department of Civil and Mechanical Engineering and professor of eivil engineering in King's College during 1935-46.
The following doctorates have been conferred: D.Sc. on Elsie M. Widdowson (Imperial College) ; D.Se.(Eng.) on Hugh Ford (Imperial College), H. C. H. Gurney and Harry Walker (external students).

\section{Royal Society of Edinburgh : Officers for 1948-49}

Ar a statutory meeting of the Royal Society of Edinburgh, held on October 25, the following officers and members of council were elected: President: Sir William Wright Smith; Vice-Presidents: Prof. W. M. H. Greaves, Prof. James P. Kendall, Sir Ernest Wedderburn, Prof. A. C. Aitken, Prof. E. P. Cathcart, Sir Alexander Gray; General Secretary: Dr. J. E. Richey ; Secretaries to Ordinary Meetings : Prof. E. T. Copson, Prof. Arthur Holmes ; Treasurer : Mr. Andrew White Young; Curator of Library and Museum : Dr. John E. Mackenzie ; Ordinary Members of Council: Prof. A. D. Hobson, Prof. W. O. Kermack, Dr. John Weir, Prof. J. H. Gaddum, Prof. G. D. Preston, Prof. S. J. Watson, Mr. R. Ll. Gwilt, Prof. J. N. Davidson, Mr. Edmund G. Dymond, Mr. Charles W. Parsons, Prof. R. W. Wheldon, Prof. E. M. Wright.

\section{Institute for the Study of Animal Behaviour}

AT the annual general meeting of the Institute for the Study of Animal Behaviour, held on October 10 in the rooms of the Linnean Society, Dr. W. H. Thorpe, of the Department of Zoology, Cambridge, was elected president in succession to Prof. Edward Hindle. Dr. Thorpe, who is a leading British worker in the field of animal behaviour, is a member of the editorial board of Behaviour, the new international journal devoted to this subject. Dr. P. H. T. Hartley, of the Edward Grey Institute, Oxford, was elected joint honorary secretary with Prof. Alastair N. Worden, while Mr. James Fisher, a former honorary secretary, was elected honorary treasurer. The following were elected to serve as members of Council : Mr. R. J. Bartlett (London), Dr. J. T. Edwards (London), Dr. John Hammond (Cambridge), Prof. A. C. Hardy (Oxford), Prof. Edward Hindle (London), Prof. Julian Huxley (Unesco), Dr. E. S. Russell (Hastings), Dr. Arthur Walton (Cambridge) and Dr. C. W. M. Whitty (Oxford).

\section{Announcements}

A Discussion on "The Theory and Practice of New Techniques in Separation and Purification", to be held by the Chemical Society on November 25, has been arranged by Dr. R. P. Linstead. There will be two sessions : "Chromatography and Partition Chromatography", at 2.30 ; "Ion Exchange", at 7.

A complimentary dinner was given on October 22 to Prof. John Read by the members of the Chemical Society of the University of St. Andrews to mark the celebration of his silver jubilee as professor of chemistry in the University, to which he came in 1923 from the chair of organic chemistry at the University of Sydney. Mr. A. R. Battersby, president of the Society, presided over a representative gathering, which included Sir James Irvine, principal of the University and a former occupant of the chair of chemistry.

ERratum.-In Nature of October 30, p. 690, under "The Night Sky in November", line 8, for "easterly" read "westerly". 